\title{
KEMAMPUAN MANAJERIAL PIMPINAN PONDOK PESANTREN DALAM PENGELOLAAN SUMBER DAYA MANUSIA
}

\author{
SUARGA \\ Fakultas Tarbiyah dan Keguruan UIN Alauddin Makassar \\ Jl. HM. Yasin Limpo No. 36 Makassar \\ Email: suargabk@gmail.com
}

\begin{abstract}
:
Islamic boarding school is an institution that can not be separated from the phenomenon of cooperation, considering the boarding school is a manifestation of the ideals or desire to create a successor cadre or santri who are experts in the field of science, especially religious knowledge. Pesantren also must realize the ability to develop and practice the religious knowledge in the midst of society. Noble ideals or desires are difficult to be realized if only done by a kiai or caregiver, because human nature does have limitations, so it takes the involvement of various humans through the process of cooperation in realizing these ideals or desires. The dynamics of pesantren development when juxtaposed with educational institutions that once appeared in Indonesia, is the oldest system of education today and is considered an indigenous Indonesian product. This education was originally an Islamic religious education that started since the emergence of Islamic society.
\end{abstract}

Keywords: Managerial Leadership Islamic boarding school, Human Resources

\section{PENDAHULUAN}

endidikan pada dasarnya adalah usaha sadar menumbuh kembangkan potensi sumber daya manusia peserta didik dengan cara mendorong dan memfasilitasi kegiatan belajar mereka. Secara detail, dalam UndangUndang RI Nomor 20 Tahun 2003 tentang Sistem Pendidikan Nasional Bab 1 Pasal (1), pendidikan didefinisikan sebagai:

Usaha sadar dan terencana untuk mewujudkan suasana belajar dan proses belajar agar peserta didik secara aktif mengembangkan potensi dirinya untuk memiliki kekuatan spiritual keagamaan, pengendalian diri, kepribadian, kecerdasan, akhlak mulia, serta keterampilan yang diperlukan dirinya, masyarakat, bangsa dan Negara (UU RI, 2007).

Pendidikan merupakan salah satu aspek penting bagi kehidupan manusia, karena dengan pendidikan manusia dapat mengembangkan diri dan menjalankan fungsinya sebagai khalifah di bumi. Pendidikan juga merupakan suatu usaha atau kegiatan yang dijalankan dengan sengaja, teratur, dan berencana dengan maksud mengubah atau mengembangkan perilaku yang diinginkan. Pendidikan pada hakekatnya merupakan usaha sadar yang dilakukan peserta didik untuk mengembangkan keperibadian dan kemampuan di dalam dan di luar sekolah yang berlangsung seumur hidup.

Pendidikan memegang peranan penting di dalam perkembanganilmu 
pengetahuan dan teknologi. Manusia dituntut memiliki ilmu pengetahuan keterampilan dan sikap-sikap tertentu di dalam menghadapi kelangsungan hidup dan segala masalah yang semakin kompleks.

Begitupun salah satu hasil ciptaan manusia modern dewasa ini ialah berbagai jenis dan bentuk organisasi, baik yang berada di lingkungan kenegaraan maupun di luarnya, seperti organisasi yang bergerak di bidang keniagaan, di bidang politik, di bidang sosial dan bahkan juga organisasi-organisasi nirlaba. Untuk mengelola berbagai jenis organisasi tersebut, diperlukan para manajer dalam jumlah yang besar dengan beraneka ragam persyaratan yang menyangkut antara lain kemampuan memimpin, pengetahuan dan keterampilan. Keperluan tersebut dirasakan baik di Negara-negara yang sedang berkembang. Demikian mendesaknya pemenuhan akan para manager itu sehingga berbagai usaha dilakukan secara intensif untuk mempersiapkan semakin banyak orang berperan sebagai manager yang efektif. Bukan hanya itu, para ilmuan pun terus bekerja keras untuk mengembangkan teori manajemen sehingga para manajer di lapangan semakin mampu menjalani proses manajemen itu dengan tingkat efesiensi, efektifitas dan produktifitas yang tinggi.

Pondok pesantren adalah sebuah lembaga yang tidak bias terlepas dari fenomena kerjasama, mengingat pondok pesantren adalah perwujudan dari citacita atau keinginan mencipta kader penerus atau santri yang ahli di bidang ilmu pengetahuan, khususnya pengetahuan agama. Pesantren juga sekaligus harus mewujudkan kemampuan untuk mengembangkan dan mengamalkan ilmu pengetahuan agama tersebut di tengah-tengah masyarakat. Cita-cita atau keinginan luhur tersebut sulit terwujud bila hanya dilakukan oleh seorang kiai atau pengasuh, karena secara kodrat manusia memang mempunyai keterbatasan, sehingga diperlukan keterlibatan berbagai manusia melalui proses kerjasama dalam mewujudkan cita-cita atau keinginan tersebut.

Dinamika perkembangan pesantren jika disandingkan dengan lembaga pendidikan yang pernah muncul di Indonesia, merupakan system pendidikan tertua saat ini dan dianggap sebagai produk Indonesia yang indigenous. Pendidikan ini semula merupakan pendidikan agama Islam yang dimulai sejak munculnya masyarakat Islam di Nusantara pada abad ke-13. Beberapa abad kemudian penyelenggaraan pendidikan ini semakin teratur dengan munculnya tempat-tempat pengajian. Bentuk ini kemudian berkembang dengan pendirian tempat-tempat menginap bagi para pelajar (santri), yang kemudian disebut pesantren. Meskipun bentuknya masih sangat sederhana, padawaktu itu pendidikan pesantren merupakan satu-satunya lembaga pendidikan yang terstruktur, sehingga pendidikan ini dianggap sangat bergengsi. Di lembaga inilah kaum muslimin Indonesia mendalami doktrin dasar Islam, khususnya menyangkut praktek kehidupan keagamaan. 
Secara fungsional pendidikan disiapkan bagaimana menyiapkan manusia agar hidup lebih baik secara pribadi maupun kelompok sebagai warga masyarakat, bangsa maupun antar bangsa. Bagi seorang muslim masa depan mencakup kehidupan di dunia dan pandangan tentang kehidupan hari kemudian yang bahagia. Pada sebuah lembaga pendidikan, kepala sekolah adalah bapak sekaligus ibu bagi semua personil yang bertugas di Sekolah tersebut. Hal ini memberikan konsekuensi logis bahwa seorang kepala sekolah haruslah mempunyai tingkat kemampuan lebih sehingga dapat mengontribusi segala kebutuhan guru-guru yang bersifat psikis dan bahkan terkadang bersifat fisik. Kondisi ini memaksa kepala sekolah untuk dapat memosisikan diri sebagai mana yang diinginkan anak buahnya, guru-guru. Meskipun kepala sekolah sendiri sebenarnya seorang manusia, yang tidak luput dari kesalahan dan kekhilafan, sehingga sangat naif jika tuntutan tersebut bersifat harus.

Kurangnya gaya kepemimpinan dari kepala sekolah akan mengurangi kinerja tenaga kependidikan dan tenaga pengajar serta memberikan dampak yang signifikan terhadap keberlangsungan dari sekolah tersebut. Selain itu, kurangnya gaya kepemimpinan juga dapat menimbulkan gejala-gejala masalah di lingkungan sekolah seperti masih banyaknya sekolah yang prestasi peserta didiknya tergolong rendah, tenaga pengajar dan tenaga kependidikan serta peserta didik kurang disiplin, tenaga pengajar yang memiliki kemampuan dalam mengelola pembelajaran dan komitmennya terhadap tugas relatif rendah, dan lambatnya tenaga kependidikan dalam melayani kebutuhan peserta didik. Sebagai seorang kepala sekolah perlu mengembangkan tenaga pengajar dan tenaga kependidikan sehingga dapat membangun iklim motivasi yang menghasilkan tingkat produktifitas yang tinggi.

Langkah yang dilakukan dengan harapan agar guru sebagai ujung tombak dari sebuah proses pendidikan dapat melahirkan peserta didik yang berkamuan dan berkemampuan untuk senantiasa untuk meningkatkan kualitasnya secara terus menerus dan berkesinambungan (continuous quality improvement).

Oleh karena itu sumber daya manusia di lembaga pendidikan merupakan unsure terpenting dalam pendidikan. Sebab manajemen sumber daya manusia diperlukan untuk meningkatkan efektivitas sumber daya manusia dalam organisasi. Tujuannya adalah memberikan kepada organisasi satuan kerja yang efektif. Untuk mencapai tujuan ini, studi tentang manajemen personalia akan menunjukkan bagaimana seharusnya instansi mendapatkan, mengembangkan, menggunakan, mengevaluasi, dan memelihara karyawan dalam jumlah (kuantitas) dan tipe (kualitas). Manajemen sumber daya manusia adalah suatu proses menangani berbagai masalah pada ruang lingkup karyawan, pegawai, buruh, manajer dan tenaga kerja lainnya untuk dapat menunjang aktivitas instansi demi mencapai tujuan yang telah ditentukan (Hamriani, 2014: 14 - 15).

Sumber daya manusia dalam lembaga pendidikan merupakan salah satu 
yang menentukan baik buruknya lembaga pendidikan. Sedangkan sumber daya manusia baik tidaknya kinerjanya ditentukan oleh peran kepala sekolah. Sebab kepala sekolah sebagai manajer harus mampu mengatur dalam hal ini mulai dari proses merencanakan, mengorganisasikan, memimpin dan mengendalikan usaha anggota- anggota organisasi serta pendayagunaan seluruh sumber daya organisasi dalam rangka mencapai tujuan yang telah ditetapkan. Begitupun yang telah diterapkan di Pesantren Putri Ummul Mukminin sesuai dengan tujuan yang telah ditetapkan namun belum mencapai kemaksimalan karena beberapa kendala seperti kurangnya tenaga pendidik yang professional.

Lembaga pendidikan Muhammadiyah atau Aisyiyah memiliki tujuan yang amat mendasar dan jauh ke depan, yakni membangun masyarakat "Baldatun Tayyibatun Wa Rabbun Ghafur". Pondok Pesantren Putri Ummul Mukminin Aisyiyah wilayah Sulawesi Selatan didirikan berdasarkan tuntutan dinul Islam yang berlandaskan al-Qur'an dan al-Sunnah dengan harapan terwujudnya putri-putri muslimah yang beraqidah bersih, beriman kokoh, istiqomah serta cakap dan ilmuwan seperti halnya istri Rasulullah SAW, Aisyah r.a yang bergelar Ummul Mukminin.

Dengan kenyataan ini guru memiliki tanggung jawab yang besar untuk memperbaiki akhlak anak didiknya, begitupun staf tata usaha memiliki tanggung jawab besar dalam mengelolah sumber daya sekolah. Tetapi ada masalah yang sering dihadapi pimpinan pondok diantaranya adalah kurangnya tenaga pendidik yang kurang profesional, rendahnya kemampuan guru-guru dalam menyusun perencanaan dan pengembangan pembelajaran.

Dari latar belakang di atas, maka permasalahan dalam penelitian dapat dirumuskan, sebagai berikut:

1. Bagaimana peranPimpinan Pondok dalam mengelol sumber daya manusia?

2. Bagaimana hasil pengelolaan sumber daya manusia pada suatu Pondok Pesantren?

\section{KAIIAN TEORETIS \\ Manajerial Pimpinan Pondok \\ Pengertian Manajemen}

Manajemen adalah melakukan suatu pekerjaan melalui orang lain (Management is getting done through other people). Definisi tersebut kelihatannya masih belum lengkap, karena manajemen sebagai penggerak dalam organisasi itu untuk mencapai tujuan. Disamping itu, perlu juga dijelaskan bagaimana orangorang lain itu mencapai tujuan melalui kerja sama. Oleh karena itu, definisi yang kemudian berkembang adalah bahwa "manajemen adalah proses pencapaian tujuan melalui kegiatan-kegiatan dan kerjasama orang-orang lain”.

Pengertian manajemen menurut George R. Terry bahwa manajemen merupakan sebuah proses yang khas, yang terdiri dari tindakan-tindakan: 
perencanaan, pengorganisasian, penggiatan dan pengawasan, yang dilakukan untuk menentukan serta mencapai sasaran-sasaran yang telah ditetapkan melalui pemanfaatan sumber daya manusia dan sumber-sumber lain (Mulyono, 2008: 1516).

Dengan demikian, dapat dipahami bahwa manajemen adalah sebuah proses yang khas terdiri dari perencanaan, pengorganisasian, penggerakan dan pengawasan serta evaluasi yang dilakukan pihak pengelola organisasi untuk mencapai tujuan bersama dengan memberdayakan sumber daya manusia dan sumber daya lainnya.

\section{Fungsi Manajemen}

Manajemen adalah proses untuk mencapai tujuan-tujuan organisasi dengan melakukan kegiatan dari empat fungsi utama manajemen, yaitu: planning (perencanaan); organizing (pengorganisasian); actuating (pelaksanaan); dan controlling (pengawasan).

\section{a. Perencanaan (Planning)}

Perencanaan adalah fungsi dasar (fundamental) manajemen. Manajemen pasti berangkat dari sebuah perencanaan karena fungsi-fungsi yang lain akan efektif dan efisien apabila terlebih dahulu direncanakan dengan baik.

Menurut G.R Terry perencanaan adalah memilih, menghubungkan fakta dan membuat serta menggunakan asumsi-asumsi mengenai masa datang dengan jalan menggambarkan dan merumuskan kegiatan-kegiatan yang diperlukan untuk mencapai hasil yang diinginkan (Malayu S.P Hasibuan, 2001: 90).

Perencanaan dilakukan untuk menentukan target dari tujuan organisasi ataupun bias juga perusahaan secara keseluruhan dan untuk memikirkan cara terbaik untuk mencapai tujuan yang ditetapkan atau definisi dari planning ini sebagai proses dalam menyusun tujuan maupun sasaran organisasi yang memperlihatkan cara-cara pencapaian target atau tujuan yang telah ditetapkan sebelumnya.

Perencanaan merupakan alat pertama dalam proses manajemen. Secara sederhana, perencanaan merupakan cara rasional dan sistematik dalam meramalkan masa depan sebuah organisasi atau merupakan sebuah proses dalam persiapan menghadapi perubahan dengan merumuskan tindakan di masa depan. Perbedaan antara manajer yang sukses dan yang tidak sukses terletak pada prosedur perencanaan (Wukir, 2013: 24).

Perencanaan adalah langkah pertama yang harus diperhatikan oleh manajer dan para pengelola pendidikan Islam. Perencanaan merupakan hal penting yang hendaknya ada dalam manajemen lembaga pendidikan Islam. Tanpa perencanaan yang baik, lembaga pendidikan Islam tidak akan maju dan berkualitas (Prim Masrokan Mutohar, 2013: 40).

Perencanaan atau planning merupakan langkah awal yang harus dilakukan 
dalam pengaplikasian fungsi-fungsi manajemen karena perencanaan merupakan pondasi awal. Dalam kaitannya dengan perencanaan pengembangan lembaga pendidikan, dapat dilakukan beberapa langkah antara lain:

1. Mengkaji kebijakanyang relevan

2. Menganalisis kondisi lembaga

3. Merumuskan tujuan pengembangan

4. Mengumpulkan datadaninformasi

5. Menganalisis datadan informasi

6. Merumuskan dan memilih alternatifprogram

7. Menetapkan langkah-langkah kegiatan pelaksanaan (Baharudin dan Makin, 2010: 99 - 100).

\section{b. Pengorganisasian (Organizing)}

Pengorganisasian adalah fungsi manajemen dan merupakan suatu prosesyang dinamis. Pengorganisasian dapat diartikan sebagai proses penentuan pekerjaan- pekerjaan yang harus dilakukan pengelompokan tugas-tugas dan membagi-bagikan pekerjaan kepada setiap personalia, penetapan departemendepartemen (subsistem) serta penentuan hubungan-hubungan. Organizing berasal dari kata organize yang berarti menciptakan stuktur dengan bagian bagian satu sama lain saling terkait dalam keseluruhannya.

Kegiatan menyusun berbagai elemen dalam sebuah lembaga pendidikan maupun instansi merupakan kegiatan manajemen yang secara khusus disebut sebagai pengorganisasian. Hal ini memperjelas bahwa di antara fungsi manajemen adalah menyusun dan membentuk berbagai hubungan kerja dari berbagai unit untuk menjadi sebuah tim yang solid. Tim yang solid akan member kekuatan. Apabila terjadi kesatuan kekuatan dari berbagai elemen sistem untuk mencapai tujuan dalam lembaga maupun organisasi, manajemen dianggap berhasil (Didin Kurniadin dan Imam Machali, 2012: 192).

Pengorganisasian berarti menempatkan segala sesuatunya pada tempatnya sesuai dengan struktur yang saling berkaitan satu sama lainnya.

\section{c. Pengarahan atau Pelaksanaan (Actuating)}

Menurut G.R. Terry “Pengarahan atau pelaksanaan adalah membuat semua anggota kelompok agar mau bekerja sama dan bekerja secara ikhlas serta bergairah untuk mencapai tujuan sesuai dengan perencanaan dan usaha-usaha pengorganisasian" (Hasibuan, 2001: 137).

Pelaksanaan dalam lembaga pendidikan Islam. Dari seluruh rangkaian proses manajemen. Pelaksanaan merupakan fungsi manajemen yang paling utama. Dalam fungsi perencanaan dan pengorganisasian lebih banyak berhubugan dengan aspek- aspek abstrak proses manajemen, sedangkan fungsi actuating justru lebih menekankan pada kegiatan yang berhubungan langsung dengan orang-orang dalam organisasi lembaga pendidikan. Dalam konteksini, 
George R. Terry (1986) mengemukakan bahwa actuating merupakan usaha menggerakkan anggota-anggota kelompok sedemikian rupa hingga mereka berkeinginan dan berusaha untuk mencapai sasaran organisasi dan sasaran anggota-anggota organisasi tersebut, karena para anggota itu juga ingin mencapai sasaran-sasaran tersebut.

\section{d. Pengawasan atau pengendalian (Controlling)}

Pengawasan atau pengendalian menurut Earl P. Strong adalah proses pengaturan berbagai faktor dalam suatu perusahaan, agar pelaksanaan sesuai dengan ketepatan-ketepatan dalam rencana (Hasibuan, 2001: 241).

Pengawasan atau pengendalian menurut G. R. Terry adalah sebagai proses penentuan, apa yang harus dicapai yaitu standar, apa yang sedang dilakukan yaitu pelaksanaan, menilai pelaksanaan sesuai dengan rencana yaitu selaras dengan standar.

\section{Sumber Daya Manusia \\ Pengertian Sumber Daya Manusia}

Dalam rangka persaingan organisasi atau perusahaan harus memiliki sumber daya yang tangguh. Sumber daya yang dibutuhkan untuk menjalankan organisasi tidak dapat dilihat sebagai bagian yang berdiri sendiri, tetapi harus dilihat sebagai satu kesatuan yang tangguh membentuk suatu sinergi. Dalam hal ini peran sumber daya manusia sangat menetukan. Semula sumber daya manusia merupakan terjemahan dari "human resources", namun ada pula ahli yang menyamakan sumber daya manusia dengan "manpower" (tenaga kerja). Bahkan sebagian orang menyetarakan pengertian sumber daya manusia dengan personal (personalia, kepegawaian, dan sebagainya) (Edy Sutrisno, 2014: 5).

\section{Tujuan Manajemen Sumber Daya Manusia}

Manajemen sumber daya manusia diperlukan untuk meningkatkan efektivitas sumber daya manusia dalam organisasi. Tujuannya adalah memberikan kepada organisasi satuan kerja yang efektif. Untuk mencapai tujuan ini, studi tentang manajemen personalia akan menunjukkan bagaimana seharusnya instansi mendapatkan, mengembangkan, menggunakan, mengevaluasi, dan memelihara karyawan dalam jumlah (kuantitas) dan tipe (kualitas). Manajemen sumber daya manusia adalah suatu proses menangani berbagai masalah pada ruang lingkup karyawan, pegawai, buruh, manajer dan tenaga kerja lainnya untuk dapat menunjang aktivitas instansi demi mencapai tujuan yang telah ditentukan (Hamriani: 14-15). Tujuan-tujuan manajemen sumber daya manusia terdiri dari empat, yaitu:

a. Tujuan Organisasional

Ditunjukkan agar dapat mengenali keberadaan manajemen sumber daya manusia (MSDM) dalam memberikan konstribusi pada pencapaian efektivitas organisasi. Walaupun secara formal suatu manajemen sumber daya manusia 
diciptakan untuk dapat membantu para manajer, namun demikian para manajer tetap bertanggung jawab terhadap kinerja karyawan.

b. Tujuan Fungsional

Ditujukan untuk mempertahankan konstribusi departemen pada tingkat yang sesuai dengan kebutuhan organisasi. Sumber daya manusia menjadi tak berharga jika manajemen sumber daya manusia jika manajemen sumber daya manusia memiliki criteria yang lebih rendah dari tingkat kebutuhan organisasi.

c. Tujuan Sosial

Ditujukan untuk secara etis dan sosial merespon terhadap kebutuhan dan tantangan masyarakat melalui tindakan meminimalisir dampak negatif terhadap organisasi. Kegagalan organisasi dalam menggunakan sumber dayanya bagi keuntungan masyarakat dapat menyebabkan hambatanhambatan.

d. Tujuan Personal

Ditujukan dalam membantu karyawan dalam pencapaian tujuannya, minimal tujuan-tujuan yang dapat mempertinggi konstribusi individual terhadap organisasi. Tujuan personal karyawan harus mempertimbangkan, dipensiunkan, atau memotivasi. Jika tujuan personal tidak dipertimbangkan, kinerja dan kepuasaan pegawai dapat menurun dan pegawai dapat meninggalkan institusi.

Pelaksanaan adalah bentuk aplikasi dari semua yang telah direncanakan untuk mencapai tujuan yang diinginkan, dalam pelaksanaan, kepala sekolah berperan penting untuk menggerakkan seluruh aktivitas yang ada di lembaga pendidikan. Pelaksanaan dalam hal pengelolaan sumber daya manusia yang telah diamati di SMA Ummul Mukminin yakni pembinaan guru dan staf dan bekerja sesuai dengan job description yang jelas.

\section{Pembinaan Guru dan Staf}

Pembinaan member pengarahan dan bimbingan kepada sumber daya manusia di sekolah guna mencapai suatu tujuan tertentu. Pembinaan guru dan staf yang diamati yakni dalam bentuk pelatihan, karena seorang pegawai itu sangat penting karena walaupun bagaimana seorang guru pasti memiliki kekurangan sehingga adanya pelatihan tersebut dapat membantu guru agar dapat mengembangkan pengetahuannya.

Dari berbagai pendapat di atas dapat disimpulkan bahwa pelatihan untuk para tenaga pendidik dan kependidikan sangat penting karena dalam suatu lembaga pendidikan memiliki pengaruh untuk meningkatkan kualitas sekolah, di antara pelatihan yang telah dilaksanakan dalam pondok pesantren.

\section{Bekerja Sesuai Job}

Lembaga pendidikan merupakan suatu system yang diadakan dan dirancang untuk mencapai hal-hal yang tidak dapat dicapai individu-individu secara sendiri- 
sendiri. Orang-orang yang ada dalam lembaga tersebut memiliki tugasnya masingmasing. Tugas yang dilakukan oleh setiap individu mendefinisikan suatu posisi. Semua posisi yang identik atau mirip akan membentuk suatu pekerjaan dalam organisasi.

Pembagian tugas ini diadakan untuk mendukung agar proses interaksi antar manusia dapat berjalan dengan baik. Demikian juga di dalam kehidupan sekolah, pembagian tugas ini dilaksanakan dengan tegas oleh kepala sekolah, sehingga masing-masing kelompok dan orang-orang dengan jelas melakukan tugas apa, kapan, dan bagaimana melakukan tugas tersebut. Job description ini merupakan manifestasi dari pemberdayaan sumber daya manusia.

\section{DAFTAR PUSTAKA}

Amirin, Tatang M, Menyusun Rencana Penelitian, Ed,1, Cet. 2; Jakarta: Rajawali, 1990.

Baharudin dan Makin, Manajemen Pendidikan Islam, Malang: UIN-Maliki Press, 2010.

Bangun, Wilson, Manajemen Sumber Daya Manusia, Jakarta: Erlangga, 2012.

Depertemen Pendidikan dan Kebudayaan, Kamus Bahasa Indonesia, Cet. IV; Jakarta Balai Pustaka, 2005.

Halim, A., dan dkk., Manajemen Pesantren, Cet.l; Yogyakarta: Pustaka Pesantren, 2005.

Hamriani, Manajemen Sumber Daya Manusia, Cet. I; Makassar Alauddin University Press, 2014.

Hasibuan, Malayu S.P., Manajemen Dasar, Pengertian, dan Masalah, Cet.l; Jakarta: Bumi Aksara, 2001.

Http://pppum.sch.id/index.php/profil, 25 Januari 2016.

Kurniadin, Didin dan Imam Machali, Manajemen Pendidikan Konsep dan Prinsip Pengelolaan Pendidikan, Jogjakarta: Ar-RuzzMedia, 2012.

Masyhud, M. Sulthon dan dkk., Manajemen Pondok Pesantren, Cet.l; Jakarta: Diva Pustaka, 2003.

Mutohar, Prim Masrokan, Manajemen Mutu Sekolah: Strategi Peningkatan Mutu dan Daya Saing Lembaga Pendidikan Islam, Cet.l; Jogjakarta: Ar-RuzzMedia, 2013.

Mulyono, Manajemen Administrasi dan Organisasi Pendidikan, Cet.I: Jogjakarta: ArRuzz Media, 2008.

Nurjaman, Kadar, Manajemen Personalia, Bandung: CV Pustaka Setia, 2014.

Sudjana, Manajemen Program Pendidikan untuk Pendidikan Nonformal dan Pengembangan Sumber Daya Manusia, Bandung: Falah Production, 2004. 
Suhardan, Dadang, dkk., Manajemen Pendidikan, Cet.IV; Bandung: Alfabeta, 2011.

Sutrisno, Edy, Manajemen Sumber Daya Manusia, Cet. VI: Surabaya: Kencana Prenada Media Group, 2014.

Undang-Undang R.I Nomor 20 Tahun 2003 tentang Sistem Pendidikan Nasional, Jakarta: Visimedia, 2007.

Wukir, Manajemen Sumber Daya Manusia Dalam Organisasi Sekolah, Cet. I; Jogjakarta: Multi Presindo, 2013. 